\title{
A Look at Retirement Funds in the Iranian Legal System
}

\author{
Mohammad Reza Mojtahedi ${ }^{1, *} \&$ Aidin Bagheri Hamed ${ }^{2}$ \\ ${ }^{1}$ General Law Department, Faculty of Law and Social Sciences, Tabriz University, Iran \\ ${ }^{2}$ Faculty of Law and Political Science, Tehran University of Science and Research, Tehran, Iran \\ *Correspondence: General Law Department, Faculty of Law and Social Sciences, Tabriz University, Iran. E-mail: \\ mojtehedi2004@yahoo.com
}

Received: October 21, 2018 Accepted: December 16, 2018 Online Published: January 20, 2019

doi:10.5430/sass.v6n1p28

URL: https://doi.org/10.5430/sass.v6n1p28

\begin{abstract}
Pension funds are an important pillar of the social security system of the country. Historically, retirement funds in the Iranian legal system have been a source of many problems, most notably financial deficits. The lack of prospects for the future and the uncertain program and unprofessional management, as a result of the lack of transparency and ineffective and sometimes contradictory laws, have all worked together to make retirement funds a problem in the country; this turmoil and turmoil situation And the inadequacies of funds in all respects have caused worries about the future. Reasons for the aging of the population and the decline in employment and ... have increased the seriousness of the crisis. The implementation of early-retirement laws in different periods, macroeconomic fluctuations, and neglect of misguided and non-normative outlooks and government roles, and largely one-way interactions with funds, are one of the most important reasons for the existence of a crisis in retirement funds In recent years. In Iran, the increase in the number of retirement funds has been caused by various programs and systems (various regulations); in the absence of comprehensive welfare and social security systems in the country, the stratification and distribution of decay and support Boxes will also be added. In this context, it is necessary to gain a comprehensive understanding of the status and legal system of the pension funds, with the study of how the administration and the status of the cost are spent, the inputs of these funds and the amount and group covered. In other words, the multiplicity of pension funds and the lack of coordination between these institutions and the lack of a single standard in them and the lack of respect for the fairness of the income received by retirees has caused dissatisfaction with this important group of society, because the type of services and range of support, also from the fund to the fund The difference is different, and this creates discrimination and increases the gap between the strata; it should be noted that the function and function of pension funds is international and the lack of attention to these funds can have serious consequences in the community. Currently, reforms to the rules and regulations of the pension funds and the management and management of these funds are important and important priorities, and the planned measures should be directed towards changing the situation and improving the efficiency and funds and optimal and wise use. Resources are maintained, with no loss or damage to retirement benefits.
\end{abstract}

Keywords: retirement funds, how to manage pension funds, government and pension funds, multiplication of funds, the need for reforms in retirement systems

\section{Introduction}

Social protection of people in society and the maintenance of people's livelihoods in societies is always considered as an important issue, because in social security systems, users of services and benefits require a variety of dimensions. The retirement pension is considered as one of the branches of modern social security systems and today it is considered by many different political, social, economic, legal and international aspects. Retirement is a matter that closely links to social programs, economic policies of each country. Also, the effects of retirement in legal systems, while also having diversity, can reflect the status of human indicators in a country. The conditions of a person's life reflect the economic functions and the prediction of the arrangements that the community has taken in order to emerge as a result of calm and confidence in the future. On the other hand, the social security dimensions of aging give rise to a wide range of issues (family-types of voluntary and charitable actions - private insurance - social assistance - mandatory social insurance schemes-social insurance) Which organizes the general welfare system of 
each country based on the existing elements of the economy and the political conditions governing it. The social security system, where retirement is also one of the key elements, if it is well-suited, also contributes to the pillar of politics and governance and can guarantee public trust and legitimacy of the state. The government intervention that has taken place along with the expansion of the branches of the economy has led governments to be responsible for ensuring and guaranteeing the living standards of individuals, especially the elderly, in their turn, with minimal income, to achieve a level that is proportional to dignity Humanize. Elderly is an inevitable and imminent risk; with the outbreak of this event, which is related to the person's personal body, it causes the person to suffer the consequences and consequences (Mojtahedi, 2009, p. 29). Getting a person away from work and activity in old age reduces his income and ultimately leads to his loss. Thus, confronting an old age risk poses as a necessity. Basically, the provision, compensation, and coping with the risk of aging are based on two theories: first, the need to compensate for the loss due to the lack of physical personality and the second reward for the activity of his work (Mojtahedi, 2009, p. 31).

In order to maintain the balance of affairs of the society, arrangements must be made to minimize the vulnerability of all classes. The importance and generality of social security is unimaginable for poverty reduction, the future of individuals and families and the redistribution of incomes and facilities; the crucial role of retirement funds as the most important pillar of welfare policies. General retirement systems are considered to be very important institutions for a large proportion of the population of many countries of the world, which will become even more important in the future as the populations of countries around the world have become older. The question of the desirable structure of retirement systems is a topic that, if viewed with more precise perspectives and dimensions, will lead us to a broader consensus on the role and form of public retirement plans. The emergence of a new consensus, in turn, ensures that the changes made under the name of reform will strengthen these programs and enable them to provide better services to millions of people who are hoping for it. (Thompson 2000, vol. 42). Pension systems have already been formed with two important goals of reducing poverty in society and providing adequate income, an alternative to people, especially workers, when cutting labor income; a significant reduction in poverty and a reduction in the class distance between the elderly through the introduction and expansion of systems Retirement benefits are usually based on social insurance policies or social assistance programs (from public funds). Pension funds are important all over the world. Setting up a retirement pension or retirement pension is a right that must be enjoyed by the people of the community, and the basis for this right is the deduction made over the years of service. This is a very vital right that is based on the citizenship rights that a person can enjoy from a right to a pension (right to a pension) to live in a community. This is the most important view of entitlement to pension and retirement pension. In European countries, in addition to citizenship theory, other perspectives (employment history, assistance, individual insurance, and group insurance) are also provided (Plagg and Quist, 2000: 144); surveys show that while in most countries in the world, retired people, In Iran, retirement is one of the most challenging periods of working life in Iran, which often comes with many difficulties. These challenges are so much that people know from the very beginning that retirement pensions do not allow them to live their normal life. And, in the course of their work and in the aftermath of this period, they have to work in the thought of earning money and maintaining their welfare. Second, or work after retirement. Pensioners, in spite of job loss, financial security or living standards, basically have a lifetime experience of retirement with a feeling of weakness and lack of health, and the components of life for this age group should always be with the proper state of health, independence, control and high quality of life, to be accompanied.

\subsection{Retirement and Retirement Funds}

Retirement from the dangers of social life that is inevitably imposed on the individual and the community and causes the individual's income to change and his financial situation in the future will be undermined. In addition to changing the retired person's income, his life is also subject to changes, and his efficiency and effectiveness are reduced. Therefore, the need for support and encouragement to continue the dignified and life-giving life of an individual and a dependent person, who has been trying for many years to come to power in various areas of the community, needs to be considered. Social Security is considered as the main cover for most of the dangers of social life, and retirement is also in line with the policy and social security objectives. An institution that is retired as the main sponsor of implementing social security policies in any country can be called retirement funds; therefore, in the definition of the pension fund, one can say: "To institutions that are governed by various laws (social security, service management Country, etc.), and there is a mechanism for continuing to support its members, most notably the monthly cash payment, under the title of payroll. " In other words, the fund is referred to as a firm with specific financial resources and commitments that must be made from the management and investment of these resources, although it is financially autonomous, but because the trustee has undertaken a public service, The government is more or less supervised (Badini, 2008, 5); non-cash and indirect non-cash services are also provided by some funds: such as 
health insurance services that provide medical and pharmaceutical support Or providing services such as: granting loans and loans - handing over cars and housing in the form of leasing - providing tourist and travel services .

In the ILO Conventions No. 102 and Article 25 of the Universal Declaration of Human Rights: Social security is specifically defined in the following terms: "Everyone should have the right to receive food in the event of illness, unemployment, disability, loss of care, Old and survivors. "

An aging event brings specific issues about how to cover this social hazard. This social hazard involves the adoption of long-term decisions on old age pensions by the authorities responsible for time, while these decisions also include future legal effects. This indicates the need for intergenerational solidarity. The principle of intergenerational solidarity implies the need for fairness and equitable intergenerational balance in relation to the ways of exercising and assuming social security responsibilities, including in relation to the financial resources of the system (Peters, 2009: 116).

The objectives of the social security system and, consequently, retirement must be within the framework of the general objectives of ensuring social justice - the realization of a proper welfare and distribution policy - social security, and so on; this will not be possible except by means of continuous and appropriate reforms The country, while protecting the rights of individuals, will extend the range of protection to other people without support in order to reduce the risks and increase the solidarity of society and improve the index of life in relation to various social and economic risks.

\section{Types of Forecasting of Future Supply Models for Retirement and Its Historical Evolution}

Throughout history, there have been various ways to offset the ineffectiveness of retirement income, each of which varies according to circumstances and circumstances, but they are all common in eliminating the poverty and weakness of income fraction.

\subsection{Classic and Old Practices}

These practices are mainly based on the person's orientation, and they are in the right direction to the person and their application is also limited and exceptional.

2.1.1 Individual (Savings): This method, which can already be counted from its application, especially in weak and unstable economic systems, in which the individual, with all his will and freedom, by saving At its expense, it collects and stores some of the future and issues of the Athena at that time. Savings are a typical example, but other forms of opening bank accounts and buying insurance and securities, and buying gold and various investments are individual methods (Mojtahedi, 2009: 36).

2.1.2 Assistance and assistance to others: The capture of the indigent and helpless people, and the protection of such people, is based on their religious, moral and compassionate basis. This way, due to its morality and pessimism, does not have a performance guarantee, and its sustainability and extent can fluctuate (Iraqi et al., 2007: 29). Actions such as: holding a golryzan - investing in real estate or assigning a person's will to help an elderly need need to be cited as examples of support. The more progressive form in this way was the formation of cooperative guilds that provided targeted groups according to various missions and, in the financial resources with the solidarity and participation of members, carried out good practices, including paying old age benefits. However, limitations such as lack of financial resources and the availability of aid, social problems and the large number of eligible people could not be comprehensive and comprehensive military support for the elderly (Mojtahedi, 2009: 38).

\subsection{New Techniques}

In the past, traditional past practices can not succeed in many ways, such as population growth, the spread of poverty and vulnerable groups, and the rise of longevity. Therefore, newer and more progressive systems, with the same approaches of the past, but with new tools, will combat this common social weakness (retirement).

2.2.1 The insurance system (private): Commercial insurance (or life insurance) is such that a person is aware of the fate and future in which he loses his financial and physical strength Or the household guard worried about his family and his wife and children, by resorting to the way in which there is a contract between a policyholder and the insured person (or his sponsor) in which the insured is obligated to pay The amount is determined (mostly in long-term installments) in the contract, and these payments will continue for a specified period, depending on the type of contract, and will occur with events such as: death, need of a person, ... In the private insurance system, the customer's request has a decisive role and is inherently in the form of a private contract (Mojtahedi 2009, 41). Although the historical record of this kind of insurance is longer, but it does not have the necessary and effective 
coverage, since its most important feature is being optional, so the need to establish a social insurance institution was quite tangible.

2.2.2 Civil liability regime: At a later time after the traditional system, the initiation of employer's responsibilities as the workshops become larger during the industrial revolution, has a more serious aspect, and since the type of danger and justification Responsibility in the late 19th century is undergoing a change, and the employer enters this cycle, which should not only benefit from the profits of the worker and the extent of responsibility extends to the effect. In Iran, with the formation of small industries, this, like the traditional one, depended on the employer and was optional.

2.2.3 Social Insurance: An insurance system that protects workers and employees against certain incidents and events that may arise, and is governed by a government or a public body. It offers benefits (Iraqi et al., 2007, 23). The role of the state is stronger and more serious through the protection of workers in this form of insurance.

2.2.4 Social Assistance: This type of assistance, also called general assistance, is aimed at helping people who are in need and have low incomes, and the most obvious feature of which is the provision of state funding and taxes on income and expenses It is. Because there is no beneficiary in this kind of participatory system, it is known as a non-participatory system or non-monetary system and therefore different from social insurance. For the first time, the old-age law program was drafted and implemented in Denmark in 1981 And gradually expanded to other Scandinavian countries (Mojtahedi 2009, 43).

2.2.5 Social Welfare Services: In addition to social insurance and social assistance, a new concept of social welfare or social assistance has emerged that, in order to continue to live decent lives, from public sources and help Volunteering supports the elderly and the low income, which is associated with the provision of non-cash services and benefits (Mojtahedi, 2009, 44, and 45). Social services are services provided by the government or volunteer organizations to needy people and vulnerable groups of society who, without interference, are in a poor position to promote and improve their standard of living in accordance with their human dignity. (Mojtahedi, 1388, 135).

2.2.6 PAYG system: Currently in Iran, it decides on retirement funds, which is known as the Pay-as-you-Go (PAYG) system and is a method of financing which is the current expense of retirement benefits Through paid incomes and from the tax (usually income tax). In the PAYG pension system, the premiums are paid to a single deposit account and the same account for insurance payments. The funds are in the form of deductions from the salaries of the workers and their employees to invest in these deductions and ultimately from the profit area Rmayhgzaryha, Member pensions in retirement pay. So the success of the fund depends on the correct investment (changes in pension systems in the world 1388, 20).

2.2.7 DB system or Defiend benefit plans: In this individual system, a fund is invested and at the time of employment, it pays to the deductible fund, and the employer does this. Then, the total of these deductions will be invested in the fund and when the person retires, the fund will pay him a pension from the same deductible. After his death, he will also pay pensions to eligible survivors according to the law. This system has disadvantages and advantages (changes in pension systems in the world 2009, 19).

2.2.8 DC system or Defined contribution plans: In this system, benefits are determined based on premium and stakeholder participation. When the beneficiary is retired, his pension or retirement benefits are exactly equal to the deduction plus benefit from the fund's investment. In recent years, DC programs in the world have grown exponentially and are now a common practice in most private sectors in many countries, because most employers consider high pension insurance premiums as a high cost, which can be achieved by dissolving this program and instead To propose a specific premium plan (changes in pension systems in the world 2009, 22).

\section{History of Pension Funds in Iran}

Since the beginning of the Pahlavi regime, the country's industries emerge as modern and modern, and the government becomes a little employer; the government accepts that the corollary for which it works should be of value and importance; the result of this attention It will be provided with support as a social insurance system that has the nature of supportive and social welfare benefits. Social insurance, which is based on the premiums paid by the employer (the share of wages) - the employer's premiums and compulsory social insurance, makes the system of social insurance systems, so that the government also follows the principle of tripartite as an observer Impartial and, of course, benefiting from the services of the worker and the employer, will enter this system. Social assistance has a public-health dimension (about employees and workers). Governments, by allocating a portion of its public revenue, will provide at least a handful of citizens' livelihoods, and this solution will empower the peace and security community to make the future more attractive. 
For the first time, an institution called the Precautionary Funds, which is one of the first social security mechanisms based on individual savings, is managed by the government. What is very surprising is that, despite the improvements and changes that occurred during the first Pahlavi era, in the first period (1285 to 1320) there was no supportive mechanism in the law for social security, such as the retirement of workers, the existence does not have. The exact demands of the workers and the nature of the employment of this stratum necessitate an appropriate support spectrum that, by the early years of the twenties, has become a demand for the working class in Iran. Achieving these goals was due to the serious struggles of the left-wing groups in Iran, which forced the ruling board to pass laws to protect workers. It should be noted that the first law is "The Law on Compulsory Insurance of State and Non-Governmental Workers 29/8/1322". In the year 1331, several drafts such as: the statutory pension bill for civil servants (including the complement of the Tehran municipality staff and the judiciary) - the statutory bill on social insurance for workers, but for some reason, were not enforced in that time period, until The reform was adopted on April 24, 4/4/14, and led to the establishment of an independent organization called the Social Workers' Insurance Organization. In Article 2, the organization has a legal personality and financial and administrative independence, and its finances are carried out in accordance with the principles of commerce, and the supervision of the government at the organization is exercised by the Minister of Labor. According to the third paragraph of Article 1 and paragraph 1 of Article 54 of this law, retirement is also among the sponsors of this organization. (The share of the insured was $5 \%$ and the share of the employer was 13\%). Article 55 of this law for the first time and in principle states the conditions for obtaining a retirement pension for workers: "A worker will be entitled to the right to use a retirement pension if the following conditions are met: 1 . During the employment period at least ten years, 2 . The age of the male worker to sixty five years of age and the age of the female laborer to sixty years of age. Every time a worker has worked for thirty years and has been entitled to insurance, he may apply for retirement without reaching the required age, and workers From the date of the implementation of this law until the retirement age of 1338, they can apply for retirement pensions Tigai shall be used in accordance with this law, provided that the relevant deduction from retirement has been paid from June 1328 to the retirement date. The retirement pension for workers who have been employed in the last five years to serve difficult and dangerous work A man of fifty-five years and for a female worker 50 years and for workers who have worked in tropical and bad weather for at least thirty years in the tropical and bad weather conditions, he will be sixty for a male worker and 55 years for a female worker. Hard and hazardous work, And the weather will be determined according to an order issued by the Ministry of Labor and approved by the Cabinet of Ministers. "Monthly retirement pension is equal to $40 \%$ of the average minimum wage per month of the simple worker during the last five years of work and has paid the premium. - Whenever the worker has paid more than ten years of retirement premium, for each additional year, an amount equal to one percent The last monthly wage (the average monthly wage of the last twelve months based on the remuneration of the premium worker will be paid to him) will be added to the above pension if the retired worker has a woman and child for a woman of $10 \%$ and for any child under fifteen years Five percent will be added to the above salary, but anyway Zafat should not exceed twenty percent of the original pension (Article, 57).

The Social Insurance Fund for Workers was the first comprehensive social security and retirement support package in Iran. In this law, the legislator sought to reduce the workers' inequalities by introducing supportive provisions. The Social Insurance Code of Workers was approved in 21/23/2013 with changes in the years 1342 and 1347; further retirement provisions arise. In the second part of chapter 6 of the law, the reform of the retirement age and its five-year reduction in men and women were consistent with the law.

In spite of the adoption of scattered laws in other occupational groups such as the Social Insurance Fund and Pension Fund and the Cooperatives of the Army, adopted in January 13, Particularly retired. It should be said that with the passage of the Social Security Act of 3/4/1354, it was a fundamental change and was the beginning of the life of the "Social Security Organization" and provided the basis for widespread support from the working class. The legal basis for protecting workers against retirement is Articles 76 and 77 of the Social Security Act (Na'imi et al., 2011: 292).

The Social Security Organization is a non-governmental public institution with its members: the Board of Trustees, the Board of Directors and the Managing Director and Supervisory Board. According to Article 7 of the Constitution of the Social Security Organization, the number of members of the Board of Trustees of the Fund in 2010, in accordance with the law on the amendment of Article 113 of the Civil Service Management Act, and how to determine the management of the Social Security Fund and the Pension Funds and Medical Insurance Allowances Act of 2009, including the responsibility of the Board of Trustees of the Fund There are nine people in total and they are defined as follows: a) Six persons, on the proposal of the Minister of Labor, Social Co-operation and Social Welfare and the approval of the Supreme Council for Welfare and Social Security. B) Three remaining persons in accordance with Article 2 (a) (17) of the Law on the Structure of the Comprehensive Welfare and Social Security 
System. The provisions of this article are in clear contradiction with the independence of the legal personality of the social security organization as well as the duty of the government to supervise (Naimi and Pareto, 1395, 104).

It is obligatory to mention here, since, in accordance with Article L.6 of the Law on the structure of insurance funds and insurances with an independent legal personality, this has led to conflict with the provisions set out above, that is, it is impossible to He also insisted on the independence of the legal personality of the funds and, on the other hand, the selection of the fund units, was entrusted to the government, and the principle of tripartite was ignored (Na'imi and Radi, 1395, 100).

Providers of social security funds, all wage earners (including compulsory insurance policies including workers construction workers - drivers - foreign nationals - custodial staff - employees of the Social Security Organization Rural telecommunication operators and contractors - some employees of executive agencies Articles 101 and 102 The National Service and Services Act, and optional insurers, which include free and open-ended holders of letters and trades, are optional).

Retirement in the rules and regulations of the Social Security Fund is subject to two forms: a) ordinary retirement under Article 76 of the Social Security Act. (B) Early retirement: Severe and harmful occupations (Sub-Clause 2, Article 76 of the Social Security Act, Included under the Race Protection Act, 1368- Early retirement of executive staff, Note 1, Article 103 of the Civil Service Management Act, and Article 59 of the Fifth Subsidiary Law Development - Retirement of women workers (Note 4, Article 76 of the Social Security Act) - Retirement The issue of the social security scheme for persons who paid 10 years or fewer premiums 1392 - The retirement of employees of executive agencies pursuant to Article 9 of the Law on Administrative Offenses 1993 - Retirement of the Law on Facilitation of Modernization of the Iranian Industries and Corrections Article 113 of the Third Development Plan in 1382.

\subsection{State Pensions}

The main policies and policies of the state in the field of workers' social security are remarkable. The government is now thinking of supporting other business groups, because it has gradually been felt to be a consequence of the increase in manpower. Since, with regard to the status of state servants, the state employment law of 1301 until the enactment of the law of recruitment of the State. By ratifying the State Employment Act, a new organization is established under the title, the Office of Administrative Affairs and Employment and Pensions and Pensions, which has already been undertaken by the Ministry of Finance under Article 70 of the State Employment Act, which has been independently established by the Ministry of Finance and its obligations from the Ministry of Finance and the State's Employment and Employment Organization (under the Prime Minister's Complex). Also in Article 71, ministries and government agencies were required to pay 5 / 8 per month from the rights group and the difference in the rights and maintenance of official servants and pilot servants with the extraordinary exception of the extra assurance and overtime of the fund and the mission of the servants to the country's pension fund. In addition to Article 74, the official servant can call for retirement and the government is obliged to accept: A - having at least 60 years of age with every record of service; $b$ - having at least 55 years of age at least 30 years of service.

It must be said that the starting point for the beginning of the crisis of the retirement funds is from Article 2 of the Employment Law of 1345, which, as an unqualified definition of employment law, establishes a dangerous innovation and organizes and recruits without any specific reasons He has a distinct and dissuasive public servant because there are no reasons for the exclusion of these groups with other servants. The Ministry of the Imperial Palace - Information and Security Organization of the State - Servicemen of state-owned companies - Armed Forces - Municipalities and subsidiaries and local associations - Judicial rank holders and members of the faculty of universities and state-owned scientific institutes - Shura Conservatives - Governmental institutions Excepted by law or recognition of the Office of Administrative Affairs and Recruitment and approval of the Cabinet of Ministers Foreign Ministry - Authorities (Prime Minister and Ministers, Deputy Ministers and Ambassadors and Governors of the Chairs of the Prime Ministries and Ministers).

Article 98 of the Employment Law of 1345 states: "Current pensions of current and current pensioners will continue to be paid from the State Pension Fund in accordance with former laws and regulations. If the coefficient of the salary of the official salary of the employed persons is changed, the state is obliged to pay the cost of living has changed this, restoring retirement pensions and duty payers. "

The actual retirement pension required an individual to be met by a servant. According to Article 27 of the same law, these terms were: the attorney has paid or paid at least 10 years of the entire retirement pension. The age of a full-time male is 60 years old and the woman's age is 55 years old (Na'imi et al., 2011, 291). According to the fund's opinion, the pension is one-quarter average pension rights for the duration of the retirement pension, which did not 
exceed the four-fifth of the average salary. Also, in the event of a retired or disabled person's salary, a fourteen-quarters pension or disability pension would be divided equally among his eligible survivors.

The establishment of a state pension fund and the duty of servants of state enterprises (affiliated to the Office of Administrative Affairs and Employment), under article 35 of the employment regulations of government companies in Article II of the State Employment Act of 5 / 3 / 1973, was approved by the Joint Commission of Parliament. The fund was based on the protection of staff against the effects of aging and disability and death approved by the State Council under the auspices of the State Council of Finance, Minister of Labour and Social Affairs and Secretary - General of the State and Employment Affairs Authority or its deputies. Accordingly, it was established that the statute of the fund was prepared by the executive and employment organization of the country and approved the approval of the ministry of ministers. In the continuation of the process, state enterprises were obliged to cut seven per cent of the salaries of each of its servants for the retirement of the servant's share and act to pay it to the pension fund. In this process, companies need to add up to $14 \%$ of its employees ' salaries to these retirement fractions (Akbari, 1395: 206).

In article 101 on the method of operation and use of funds in the fund, the fund statute will be $8 / 3$. In addition, according to article 105, one of the three pillars of the organization can be chaired by the Council, the Board of Employment Complaints and the Secretary - General. Since it was concerned with the retirement and duty of formal staff within the administrative and employment functions of the organization, part of the council 's decisions were assigned to the two departments of employment (which led to the provision of five sections A - article 104, the retirement department of officials and pensioners) and the department of and ceremonial affairs. According to articles by the State Council for Administrative Affairs and Employment, the Council of Internal Affairs and Employment Affairs, Secretary - General of the State Department for Administrative Affairs and Employment, Secretary - General of the State Department for Administrative Affairs and Budget, the chairman of the State Department for Administrative Affairs and Employment, the chairman of the State Department for Administrative Affairs and Employment, the chairman of the State Department for Administrative Affairs and Employment, and the approval of the Cabinet of Ministers. The Shura Council resolutions approved a vote of four of the members present at the meeting, officially and valid (Akbari 1395, 113).

The Civil retirement organization has the following: The Council - Head -. 1976 (Article 5 of the 1354 Statute). It can be noted with regard to the organization's statute, that the shape of the organization of the organization was similar to a public enterprise. (in order to confirm this view, article 4 of 1354 statute). The State Security Organization Council is also made up of the Secretary - General of the State Department for Administrative and Employment Affairs, vice general of the Central Bank, vice - general of the Ministry of Economy and Finance, deputy director of the Ministry of Social Welfare, deputy director of the Ministry of Social Welfare, Deputy Chairman of the Program and Budget in Budget Affairs (Article 6 of the 1354 Statute).

In the $1950 \mathrm{~s}$, the country " s pension fund will also emerge three more in the field of retirement: the pension fund and the servants ' duty of state - owned firms - the state 's pension centre - the welfare Council of retirees and the state owned.

One of the most important private institutions of decision makers in the field of pensioners is the welfare council of country. The establishment of a State Council for the of State, as one of the institutions of decision making in matters and issues of state retirees, approved the implementation of the amendment to the Cabinet of Ministers 10 / 8 / 1976, under which the council was set up to supervise the implementation of the regulation and to set the terms and conditions mentioned in article 2, a council called the State Council. On the second article of this decree, the amount of budget consumed in the allocation of the budget of the budget in 1976 was defined by the recognition of the Council:

1 - To contribute to the housing of pensions and pensions and legal heirs they receive from a state pension fund, in case they and their spouse and children are not a private home, payment of part of the rent or the payment of the loan interest granted by government agencies and banks to pensioners.

2 - Reinforcing the financial strength of cooperative and consumption - cooperative companies and pensioners, and retirees and pensioners to be formed or formed.

3 - Paying for the necessary and emergency expenses of pensions and, or their legal heirs to a bid by the Association.

4- The creation and management of the clubs and healthy entertainment centers for pensioners and their families and their families, or from contributing to the development and administration of existing clubs (Akbari 1395, 118).

According to Article 4 of the Council of Ministers, the members of the Council of Health and were members of the Council of Health and(chairman of the Council), Secretary - General of the Organization for Administrative and Employment Affairs, and Chairman of the Association of state. The welfare council of pensioners and pensioners had 
five main tasks. These functions include the approval of the program and the annual performance account determining the conditions and conditions mentioned in Article (2) of the Code - Review and commenting on proposals to increase the welfare of pensions and pensions in the Council. Examining and commenting on other topics on the welfare of national retirees and pensions to the council - other obligations under the regulation will be carried out by the council.

According to Article 4 of the Cabinet of Ministers, the members of the welfare council of retirees and duty agents were: the Minister of Health and Welfare (head of the council), the Secretary General of the Office of Administrative Affairs and Recruitment and the head of the Association of Retired Persons in the country. The Welfare Board of Retirees and Task Forces has five main tasks. These tasks included: approving the program and the annual performance account - determining the terms and conditions in article 2 of the Rules - reviewing and commenting on suggestions on increasing the resources of the welfare account for retirees and country-specific councilors. Reviewing and commenting on the other issues that are presented to the Council on the welfare of retirees and the country's duty-performing other tasks assigned to the Council under this Regulation.

At present, the plurality of laws governing the retirement pension in the country's pension fund should be considered to be the disadvantages of a serious reform; among them the most important laws should be: Article 124 of the State Employment Law, the Law on State Service Management 2007- The Law on Amendments to Provisions Retirement and National Recruitment Task 1368 - The Law on the Coordinated System of Payment of Pensions and Duties 1993 - The Law on Amendments to Some Regulations Regarding the Retirement of 2000 and ...

Retirement in the laws and regulations of the State Pension Fund is twofold: a) Normal retirement: Note 1, Article 103 of the State Service Management Act. B) Early retirement: single article of the law on the way of retirement of veterans of the Islamic Revolution and forced labor and ordinary people with disabilities and the occupation of hard and harmful occupations; 1988 - single article of the pre-retirement provision of state employees; 1986 - the law amending certain provisions relating to retirement, Working women, families and other employees.

\subsection{Military Retirees}

In spite of the difficult and sensitive activity of the armed forces in the country, it is essential for these categories of workers to have the benefits, in order to calm down the future, to properly carry out the assigned duties. "The Life Insurance Act and the Accidents of Armed Forces and Gendarmerie Personnel in Response to Occupational Events Occurring in Response to the Task" in the year 27/8/1335 was the first attempt to formulate the retirement plan of the armed forces. The existence of funds that were specifically linked to a group of military personnel should be considered as the first attempt to create separate groups of work groups. Funds such as: the Pension Fund and the co-operation of the country's captain since 1335; - the State Pension Fund and the Cooperative Directorate of the State Railways of Iran since 1336; - the Insurance Fund for the Armed Forces of the Kurdish and Gendarmerie Army since 1337. Chapter 6 of the Law on the Recruitment of the Imperial Armed Forces. The issue of retirement of officers and employees of the armed forces was referred to under Article 81 of the payment under the supervision of the Sepah Bank's Pension Fund. The Army and Gendarmerie Pension Fund (which is called the Sepah Bank's Pension Fund) stipulated special regulations for the retirement of the armed forces. In 1344, according to the law on the recruitment of armed forces with officers, captains and captives, the police force is also added to the law.

In 2007, under Article 174 of the Third Development Plan, it became the Armed Forces Insurance Fund and the subsection of the Social Security Organization of the Armed Forces. According to Article 5 of the Social Security Code of the Armed Forces, the members of this fund are: Armed Forces staff (Islamic Republic of Iran Army, Islamic Revolutionary Guard Corps, Islamic Republic of Iran Police, Ministry of Defense and Armed Forces Support) and their subsidiary and affiliated organizations The duty and duty of the Special Basij, as well as the retired, the duty guard and the subordinate and pensioner.

The retirement of the armed forces, despite the pooling of funds, still leaves specific employment laws; Article 110 of the Army Act of 1366: Army retirement retirement with 30 years of service or sixty years of age. Section C, Articles 108, 126, 127, and Note 2, Article 110, and Section B, Article 108 of the Army Law, refer to early retirement; alongside with this law, the retirement status of the veterans of the Islamic Revolution and the imposed war and ordinary military and law enforcement forces and the Ministry of Defense and Support The armed forces of 1367 are also amended in 1387. In Articles 77 and C, Article 121, and Note 1, Articles 123, 125 and 140 of the Labor Recruitment Law of the Islamic Revolutionary Guard Corps, and in Articles 104, 128 and 146, the IRI's regulations on retirement are also included. 


\subsection{Exclusive Insurance and Retirement Insurance Funds}

The dedicated insurance and retirement funds, which were formed on the basis of their own executive regulations, and some now also operate, and these special funds provide services to specific corporations. The formation of multiple funds at this time should be the beginning of creating problems in the field of social security and retirement. The lack of clear plans and perspectives, and the Government's willingness to expand its business, due to the immediate benefits, the effects of the adoption and the lack of financial strategy, and the source and status of manpower, are all due to the start of the crisis in retirement funds.

Table 1.

Title of the fund and the year of share and payment
establishment

\begin{tabular}{lll}
\hline $\begin{array}{l}\text { Telecommunication } \\
\text { pension from 1334 }\end{array}$ & company's & $\begin{array}{l}\text { (employee contribution } 8.5 \%-\text { the } \\
\text { share of the organization is } 75.12 \%)\end{array}$
\end{tabular}

According to the Article 30 of the employment regulations of state companies in the telecommunication company of Iran of 1356/4/1356 and the amending bill of some employment regulations of state enterprises 17/3/1358 The Revolutionary Council joins the National Pension Fund.

Pension funds, savings and welfare of the oil industry personnel based on retirement regulations and savings provisions of the staff of the National Iranian Oil Company of $1337 / 3 / 11$

Bank's retirement pension since 1342
(Employee share of 6\% Organization share 19\%)

(employee contribution $8.5 \%$ Organization's share of 17\%)
(But since the year 1377, the funds have new pillars). There are only age conditions for retirement. Men are 60 years old and women aged 55 can retire. Women under the age of 15 and men under 20 years of age will receive minimum salary for retirement. According to officials, the average service life is over 30 years old. The order of inputs per person to the fund is higher than the other funds in the case of the oil industry. The high average of years of service, in addition to the greater participation of subscribers in the provision of fund reserves, also reduces the length of time it takes to benefit from the post-retirement fund. The investment fund and its financial resources are part of the stock exchange, a part of the investment in construction affairs and affairs.

Following the formation of this bank and the transfer of a number of employees of the National Bank to the Central Bank in 2134, Central Bank has been concentrated mainly in Tehran. The central bank has its own recruitment law. It is the decision-making body for the fund, the money and money board, and the 
central bank's retirement institution acts as a current account and is centralized in an agency. According to the relevant laws, the fund has no separate legal personality. And can not participate in investments. Funding from sources and other funds of the fund has been limited to long-term deposits with banks. Although the prescribed service years are 30 years old, nonetheless, men with 25 years of service and 50 years of age and women with 20 years of service without any age limit may also be retired; early or early retirement obligations are secured by the bank; and The fund is paid and its items are very small and few. The pension fund base in the central bank is the average salary of the last year. From the insurance premium, the bank's share is 17 percent and employee's share is 8.5 percent.

Pensioner of the joint stock company for the supply and distribution of forage since 1349

Pension insurance company of the Central Insurance Company of Iran since 1350

Pension Fund and the duty of fixed-income employees of the capital's municipality and affiliated organizations since 1353 (employee share of $8 \%$ - the share of the organization $13 \%$ )

(Employee share of $9 \%$ Organization share of $18 \%$ )

(employee share of $7 \%-14 \%$ share of the organization) according to Article 25 of the statute of the joint stock company for the preparation, production and distribution of forage: 11/15/1371: with all stocks - including the share of the servant And the company's shareholding and its obligations in relation to the maintenance of the retirement pension of the relevant employee - were transferred to the National Pension Fund.

The Pension Insurance Fund of the Central Insurance Employees has been established in 1350 and is exclusively covered by central insurance staff. The funds of this fund are mainly fixed deposits Banks have been invested.

The Pension Fund of Tehran Municipality employees before the year 1353 was a part of the state pension organization, but this year it was funded. Tehran has a number of organizations and corporations. There are 18 organizations and 60 companies under the cover of the municipality of Tehran. Employees of these organizations and corporations, some are jointly funded and others are insured by the 
The National Steel Company's retirement insurance company since 1353

Pension fund of the Ports and Shipping Organization since 1353

Pension fund of the sponsor and retirement of the future builder since 1355 (employee share of $7 \%-14 \%$ share of the organization)

(Employee's share of $7 \%$ Organization's share of $14 \%$ ) social security organization. . The Tehran Municipality Pension Fund is active in various fields, including construction and construction of commercial and administrative centers in different areas of the municipality. For this purpose and in order to develop economic operations by the Fund, the Articles of Association of the Fund once in 1995 and again in the year 1381 has been reviewed.

The fund has been liquidated and despite financial resources due to lack of balance and impossibility of unrealistic privatization, support rates and numerous financial difficulties encountered The fund has been considered to resolve the fund's problem in paragraph 59 of the budget law of 1391, but the state of affairs of this fund is still unclear, and in 1396, this situation has been confused and controversial with the integration of the Social Security Fund from the parliament.

According to Article 1 of the Reform Regulation and the duty of the Employment Code of the Port Authority and according to Article 35 of the Employment Code of this Organization (approved in August, 1349) The 1353 statute has legal personality and is financially independent in terms of managing and operating resources. The Fund's revenue sources are mainly: a) The deduction provided for in regulation b) Income from the utilization of fund resources in investment activities; Purchase of securities and securities. C: Aid and gifts from the organization.

(10\% shareholder contribution $20 \%$ share of the organization) according to Article 2 of the Law establishing the Organization for the Development and Modernization of Industries of Iran and approval of the Office of Administrative Affairs and Employment of the country and the resolution of the Supreme Council for Social Security and Agreements The formation of the fund was registered as a nonprofit organization and started its activities 
Staffing for the support of attorneys and lawyers from the courts since 1355 (employee share of $8 \%$ - the share of the organization $4 \%$ )

in order to secure and enforce retirement and invalidity rights and salary obligations of the survivors of the employees of the Organization for the Development and Refurbishment of Industries of Iran and companies and subsidiaries.

is a non-state fund and Article 7 of the Administrative Code of Article 8 of the Law on the Establishment of a Lawyer's Support Fund for lawyers and practitioners of the Judiciary, Articles 14 and 15 of the law are retired.

Retirement pension of employees of (Employee's share of 7\% - According to the law on the addition Iran Fisheries Company since 1352 Organization's share of 14\%) of retirement fund staff to the State Pension Fund of the Republic of Iran approved on 17/10/1358.

\subsection{Analytical over This Course}

In Iran, along with the changes that took place in all the countries of the world in the twentieth century, and the society from the traditional form to a new society with the characteristics of urbanization, changing patterns of consumption, serious changes in population and labor force, changes in incomes and capital, and ... It was moving rapidly. The conditions of Iran, especially in the 1940's (with serious reforms in the components and social indicators), and in the 50's, with the increase in oil revenues, The size of the government is measured in terms of both the size of the duties and the responsibilities and the staffing levels. The status of the Third Development Plan funds from 1342 to 1347, as compared to the following years, has increased dramatically and has a major shock in the Iranian economy; so that the increase in oil revenues in 1352 was so much that it did not only change the fourth development plan But the fifth development plan was also rewritten. In fact, with the increase in oil revenues during this period, the government will build a more powerful structure than other community institutions. Equipping oil revenues to provide social support to the government in the form of focusing new national resources on social welfare. In this regard, institutionalization was completed by adding oil revenues. In this period, we see a slight increase in the quality of institutions and institutions in the field of welfare and social security. One of the obvious manifestations of this institution was the creation of support institutions for retired people in the country. As a result of the growth of oil revenues in the budget laws of the country, especially in 1355, we are faced with the qualitative development of the domain and policy domain of the state in retirement affairs. In order to realize the welfare state thought by the predominant social policymakers in this period, more support was given to similar European countries, which in turn was called an unprecedented trend. This idea was about welfare systems in the industrialized countries of Europe. On the other hand, it was aimed at reducing political dissent and creating support groups of the state, especially among the country's retirees.

\subsection{The Developments of the Retirement Funds from the Islamic Revolution to the Present}

After the Islamic Revolution in February 1979, the formation of a new political, legal and economic system based on the constitution and universal will have been established. Unfortunately, despite the good and comprehensive rules of law, the lack of serious will and the situation prevailing in the pre-revolutionary conditions reflected another matter. The dissatisfaction of the masses of workers and workers, despite the efforts made, could not be effective in terms of popularity. The growing poverty and the expansion of the state and, consequently, rising costs, were problems.

Article 29 of the Constitution of the Islamic Republic of Iran states: "Social security benefits in terms of retirement, unemployment, aging, disability, neglect, inability to stay, accidents, and the need for health and medical care and medical care in the form of insurance and Other is a public right and the state is obligated to provide services and financial support to a country's people according to the rules of public revenues and income from participation of people." By definition, social security is a universal, comprehensive, comprehensive, and comprehensive obligation that the state must consider for all segments of society. 
The system's supportive approach and the government's ongoing efforts to disenfranchise and support the needy have been created to create, together with insurance organizations, other institutions and supportive and other services, and each of them will be part of the mission of the social security system. During these years, attention to villages and deprived areas was at the top of government programs. The formation of the construction Jihad and the Imam Khomeini Relief Committee and the Mostazafan Foundation for helping the needy and the elderly, especially in rural areas, have led to improved livelihoods and health facilities in these areas than in the past.

With the onset of the imposed war in 1359 and the devastating effects on all areas in the country, the retirement status and funds are also subject to changes as it is assumed that the funds are one of the most important institutions of the economy in the society and the sovereignty The reason for the issues (nationalization of industries confiscation of facilities and property-purification and forced retirement of forces), which was after the Islamic Revolution in the country, was more dominant and more arrogant, and the state's role could be felt entirely on the boxes. The bad economic situation that existed during the war period was in some way justifying the intervention of the state in the funds, and since the funds, like other institutions and economic institutions of the country, were faced with their disadvantages, they were quite a fraction The sources were obvious and led them to the state as the only institution that had some kind of better capitalization. On the other hand, the government realized that, in those circumstances, the inability to repay fund liabilities to pensioners could have bad effects, and so it was trying to help the funds in this regard as well. But this period could not be sustained, because the country was in a war, and the industry was in a state of holidays and costs to confront the enemy. Hence, the amount of donations to the fund was kept low every day.

With the end of the imposed war, the government devoted itself to implementing a policy of economic and social reconstruction, often devoting revenues to post-war reconstruction and reconstruction. On the other hand, the budget deficit ( $\$ 7$ billion), heavy inflation (49\% in 1995), high unemployment of manpower, lack of capacity for investment, etc., institutions and organizations providing support and insurance services with many financial constraints Encountered The emphasis was on subsidies being transparent, and service providers, as well as health and treatment, relied as much on their revenues as possible.

In a situation where the country is not in a good position in terms of economic indicators and labor force, most pension funds, in particular the three largest pension fund providers in the country, namely the Social Security Organization, the State Retirement and Pension Fund of the Armed Forces, as well as special funds in They had their own middle-aged age and needed to invest their premium and insurers' contributions in order to offer future commitments in diverse portfolio portfolios. In this period, for example, the social support organization's ratio was close to 9 . This means that there were 9 insurers for each pensioner in the organization. It is worth noting that if the country enjoyed the boom of the economy and the developed labor market, the ratio of support in the pension funds would be much higher. However, during the period of construction, for the reasons mentioned above, most pension funds lost their high investment opportunities and, even in some cases, they devoted their resources to current expenses of the country.

Approval of the premature retirement age of social security insurers (January 28, 1367) (with at least 55 years of age and 20 years of full history) and approval of the government's human resources adjustment law, which increased costs and reduced resources of the social security organization; and perhaps points The government called for its surplus human resources, and these people, with a high age and background, without paying the premium (according to the principles and rules of insurance and calculation of insurance), have their records back to the organization Social security was transferred and immediately retired.

At that time, it felt as if the rules of the budget were not fully capable of solving the problems of the country, hence the socio-economic development program, which was somewhat long-term and had key and important issues for a certain period of time. Agenda and one of the issues mentioned in these laws were retirement funds that were reviewed in the country's development plans as part of the five-year plan of the country. The country's pension funds in the Third Development Plan are listed in the fifth chapter, the "social security system of subsidies", although in Article 174, chapter twenty two, "defense and security affairs", reference is made to the issue of retirement of military personnel. Articles 36 to 47 of Chapter Twenty-Two of the Law of the Third Plan of Economic and Social Development of the country, dealing with social security issues. In this law, the right to social insurance and social security in accordance with the twenty-ninth principle of the Constitution is a general right that the state is required, according to the law, from public revenues and revenues from people's participation, services and financial support for insuring and providing Provides social services to every single person in the country. Article 37 of this law states that insurance activities are carried out in two parts: public and supplementary. In the public insurance sector, with 
the participation of the insured, the employer and the state, the sickness insurance, retirement, disability, survivors and unemployment insurance for all insured persons, its limits are also proportional to the premiums, the financial ability of the insurers and the amount of state aid As determined by the Cabinet of Ministers. In other words, the state insurance umbrella in the third plan, according to the government's nobility on the financial ability of insurers, has been drafted solely in the area of public insurance, in line with the ability of insurers and government assistance, which seems to be in line with the total economy of the country and Past misconduct, the government has made a policy in this regard.

The government informed the inability of insurance companies and pension funds to raise the following measures in order to increase their financial strength: * Due to the government's huge debt for the employer's share and the fact that the government is the largest employer in the Iranian economy. (Roghani Zadeh, 2007: 23); the state is obliged to pay $50 \%$ of its debts to insurance companies and not to create new debt until the end of the third plan by transferring the shares of state-owned companies and property and government assets to half-plans in proportion to the activities of these organizations. Although, as has been noted, the evolution of these transfers has been the ineffectiveness of the companies that were entrusted, but at least the failure to create a new government debt to insurers was a relatively successful attempt to increase the power of these organizations.

The government, in order to mitigate the consequences of the statutory premium law in accordance with the last two years, required the government to take steps to pay wages in excess of wage increases if the wage increase did not result from job promotion. Indeed, this policy has led insurers to enjoy a certain margin of safety from potential wage losses, mainly due to rising inflation, which was often the main source of government budget deficits.

In May 2004, a comprehensive social welfare and social security law was adopted, which effectively defined the insurance policy, relief, and sponsorship scheme. But what happens in the next years in the country will cause the situation to change in a different way. The worsening of economic indicators and the sharp changes in prices and shocks that occur due to some incidents and wrong decisions in the country in the 1980s lead to a crisis of labor market. The funds are extremely vulnerable at this time, and their resources are rapidly being consumed, and the government is providing funds to donate companies that they do not intend to manage, and they are forced to This will lead to a portion of the resources of the retirement funds, and this will lead to a massive increase in the amount of retirement premiums. This era can be briefly explained, the activities with the highest risk and the lowest returns that actually lost the resources of the funds and did not have a good result, except for heavy debts. In addition to what happened during this period, there was a lack of payment of state pension funds that was made possible by increased oil revenues, but willingness to do so, and implementing comprehensive plans for the coverage and support of all individuals. Society did not come about.

In the 1990s, despite the economic downturn and the downturn in the country's economy, which also presses the funds, the government is seeking reforms such as increasing the retirement age and granting non-cash benefits and arranging for retirement funds; But work is a very long and dangerous way ahead of the government and we need to make more structural decisions.

In the Fifth Development Plan, Chapter III of Social Insurance (Articles 26 to 31), it was quite rigorous to amend pensions in the area of retirement funds and included good points, but ambitions and lack of attention to the status and conditions of this regulation Left the law to the point. In the Law on the Sixth Development Plan (art. 28, paras. 81 and 82), there are rules for assisting the government to take into account the adversary's periods and the implementation of the multi-layered system and the expiration of the average two-year period for all proceeds of all funds.

Currently (2018), public funds are mainly based on four funds: the Social Security Organization, the Pension Fund of the Armed Forces, the State Pension Fund, which are generally government employees, and the Farm Insurance Fund, the Village and the Nomadic Fund. Population Covered 73 The percentage (three and a half million) is covered by social security. 
Table 2.

Title of the fund and the year of share and payment
establishment

Airline retirement insurance of the (Employee share of 7\% - The purpose of the establishment of the Islamic Republic of Iran since 1359 Organization share of 14\%) Fund is to provide financial and welfare services and to pay salaries and retirement pensions of Iranian airline employees. The ratio of support (the ratio of the insurer and the pensioner) to the three thousand pensioners who contribute to the fund receives ten thousand retirees from the pension fund, which is far from standards.

Social and Retirement Benefit (Employee Contribution 8\% - Since its inception in 1337, it has been Officer since $1363 \quad$ Organization Share 16\%) converted into an account and then changed to the Pension Fund in 1983. Retirement affairs at the time of the fund review were carried out through the relevant department in the recruitment process, and the fund was primarily engaged in commercial activities and, in some cases, in investment and construction activities. The staff fund also covers all provincial audio and visual organizations. The executive board of the fund has a board of trustees and changes to the rules of the fund are the responsibility of the supervisory council of the organization. The fund provides its funds from the location of the organization's assistance and the activities that the organization refers to the economic sector of the fund. Activities undertaken in this area include the construction of multi-building contractors or the purchase of equipment for radio and television. The fund currently has no reserves and faces a deficit in payments.

Subunit pension and disability of banks (Joint-Stock Bank) since 1363 (employee share of $8.5 \%$ - is based on the relevant legal provision Organization's share of $17 \%$ ) and acts independently. At present, except for central bank employees, all employees of state-owned banks are covered by this fund. Prior to 2000, the employees' retirement pensions for the fund were $17 \%$ of banks and $8.5 \%$ employed. After 2000, these percentages were respectively $21 \%$ and $9 \%$ respectively. In 2005, due to the increase in payments in recent years, the Fund faced various problems. According to the Fund's officials, the deficit in payments was close to $5 \%$, from the 
Pensioner of the National Iranian Copper Industries Company since 1364

- Imam Khomeini Relief Committee from 1364

The martyr Foundation since 1988

Pension fund for the construction of jihad since 1369

-Institute of Information Retirement from 1995
(Employee's share of 7\% - 14\% share of the company)

(pension payment to rural elders in the form of Shahid Rajai's scheme)

(payment of a pension to the family of martyrs, veterans and disabled)

(Employee share of $7 \%$ Organization share of 14\%)

(Contributor's share of $10 \%$ Organization's share of $15 \%$ ) investment of 3\%, as well as the resources of banks and each bank, in proportion to the share of its retired employees in terms of number in the fund. The fund's reserves are mostly in the form of a fixed deposit with banks of $85 \%$, and also in shares of $5 \%$ and other investments of $10 \%$. The pension fund base is in the bank's fund, the average salary of the last two years and the years of service and retirement age of the fund are based on the coordinated payment system.

on the date of $11 / 13 / 1361$ with the approval of the General Assembly of the shareholders of the National Iranian Copper Industries Company and according to Chapter 11 of the Employment Code The National Iranian Copper Industries Company has begun operations. The fund is a nonprofit institution with legal personality and financial and administrative autonomy.

supported by Shahid Rajaee's Immigration Committee, which was responsible for the implementation of the Imam's Relief Committee under the Budget Act of 1364, and the needy households living in Villages and nomads over the age of 60 who do not receive any salary and state pension contributions, while they do not have the same income and financial resources as self-sufficiency, are paid monthly to the beneficiaries (Mojtahedi, 2009, p. 135).

with the support approach of the serviceman's share is based on the voluntary presence of hard and harmful businesses one to one and one half, and the state is obliged to pay the difference between insurance deductions and Retirement will calculate the contribution of the individual for the duration of the reference to the latest employment status (Naimi and Radi 1395, 236).

Integration into the National Pension Fund in February 2011 (May 1393, 119).

Article 87 and Note of that Statute of the Ministry of Information 25/4/1374 and the Articles of Association of the Fund 30/4/1378(Regular 2011, 79). 
The continuation of the past and the establishment of various and independent funds, without attention and consideration of resources and future challenges, is still a major dilemma. Because there is no justification and reason, it can be seen in the creation and multiplicity of fungus in the form of funds, especially in the context of the sixties of Iran, and the imposed war of sanctions and the critical state of the economy; it must be said that thinking, unfortunately, in the administrative and legislative system, In the shareholder (rent-seeking) and distinction (superiority) of an institution from other institutions, the problems of the present day are flooded by funds and, regrettably, in the legal and political system, the roots of this species continue to emerge. Thought has a serious presence. The government has discriminated against these discriminatory laws without any intellectual backing and justifiable justification, removing a group of employed people who are paying wages and excellent conditions and having a lower age for retirement.

\section{Factors Causing Crisis in Retirement Funds}

There are cases that are emerging as a source of crisis in pension funds, mainly in all countries, but varying in severity and intensity. In Iran, in general, the crisis cases facing retirement funds can be summarized as follows:

\subsection{Demographic Changes and Decreasing Fertility Rates}

The growing population aging population in Iran and the progressive increase in the number of pensioners and pensioners face serious challenges to retirement funds and raise fundamental concerns not only for the funds, but also for those members whose economic security and peace of mind are aging and retirement dependent. It is the right function of the boxes and the proper fulfillment of their obligations. The aging process of the Iranian population has begun, with nearly $10 \%$ of the country's population now elderly and the population movement is increasing by $30 \%$. According to the statistics center of Iran, now about $9.2 \%$ of the population of 80 million Iran are elderly in 1395 (a population of about 500,000,000 people). Demographic experts predict that by 2020 this figure will reach $10 \%$ and by 2050 this figure will reach $30 \%$, which will result in one out of every three Iranians elderly. Another thing to note is the rising age of life expectancy, which has occurred not only in Iran, but also in the EU countries, as well as the age of people has been added with advances in technology and health promotion. This also affects the retirement funds as well. Age aging (retirement) in the world from 60 to 70 years for men and women is also changing from 50 to 60 years (Mojtahedi, 2009: 31).

In addition, it should be noted that, with the increase of migration and urbanization during the two censuses of 1385 to 1390 , the share of urban population ranged from 68.4 to 71.4 percent, and the share of rural population from 31.44 to 28.5 percent it is arrived. In 1390, the urban population of the country crossed the $70 \%$ border. This is not particularly appealing to the villagers and nomads in the retirement fund (Statistical Calendar of the Pension Fund, 1395, 103).

\subsection{Severe Fluctuations in Macroeconomic Indices}

The occurrence of fluctuations in the economy of each country is probable, but the permanence and the negative of variables, especially in the field of pension funds, have serious and direct effects. In Iran, macroeconomic indicators have always been in a way that has made retirement income unsustainable. After the retirement of a person, his monthly salaries are significantly lowered, besides this unbalanced currency and inflation, and low purchasing power for a person creates a complicated situation; when this is the case, the will of the force Working for retirement is low and may even have negative consequences. The subject of inflation and the reduction in the purchasing power of insured workers and the various factors characterizing retirement pension (work experience and age), including the average wage in two years (the age varies over the years in different countries), is determined before retirement for the elimination Retirement problems apply for assistance (Talib, 1368: 111).

Changes in the level of wages and prices should be based on realistic and well-grounded legal provisions. Revenues that are offered in most retirement plans are in the form of lifelong monthly benefits that, of course, take into account changes in wages and prices (Thompson, 2000: 207).

The point that is always raised in the fundraising fund is the life span of individuals, and the pension system is always affected by this issue, because the premiums and rebate payments are usually affected by the fact that due to Fiscal weaknesses In order to correct these rates, the government usually seeks to compensate for this by allocating a note in the annual budget bills with the forecast and allocation of a part of the budget, since the sources of income in retirement funds mainly focus on these cases Based on: 1. Compulsory insurance 2. Capital investment and assets 3 . Gifts (Carbasian, 2005: 96). 
In addition to this, the funds have been saved since they have accumulated premiums over the years with this economic situation for the coming days, and they are always required to repay shortcomings and retirement pensions, From the government or spending other resources, but this situation can not continue, as the resources of the funds will end one day and the government can not continue to help it forever. In 1396, the government allocated 2,400 billion USD for retirement pensions. It should be borne in mind that the government, on the basis of price indicators, determines the amount of wages each year, which, by virtue of this, increases the amount of synchronization, increasing every year, and results in negative financial consequences both for state resources and for resources. In some funds, such as the $100 \%$ Steel Fund, they are affiliated with the state and bankrupt, or the Armed Forces Pension Fund is also 80\% dependent on the government, which is very disturbing. The government grants 1396 salaries for more than 2 million retirees from the country and a troop of 38 trillion tomans, which is equivalent to the provision of state aid to funds with a cash subsidy of 23 million families. In the last ten years, the government only allocated 2\% of its public funds to help the funds, accounting for 10\% of the budget in 1996.

\subsection{Lack of Strategy in Employment Policies}

Welfare policies provide a set of measures and programs that are implemented by the legislature and stakeholders in the community and by the executive branch in order to provide indicators of a person's worth of life in the community. Social security and its supporting branches are considered to be one of the most important welfare policies of a country and a major part of welfare policy implementation should be considered in the proper and systematic implementation of social security. The adoption of welfare policies can in turn have significant effects and consequences in a society, and the implementation and non-implementation of these policies can affect the current situation, and in particular the future of that country. The provision of livelihood and confidence in the implementation of welfare policies plays a major role in the economic, social and cultural indicators of society. According to Articles 91 and 93 of the National Employment Law, it is stipulated that a pension is to be considered as a social right (Na'imi and Radi, 1395, 190). Retirement pension is an alternative source of income; in retirement, a situation occurs in which a person, by reason of his or her compulsion and due to his or her age, or having a certain work record, or both, is entitled to benefits and benefits Work resigns (Na'imi et al., 1390: 293).

Wrong welfare policies and lack of approach in this regard can have very bad consequences in society, the most important of which is the lack of psychological and social security in the community, which has many consequences. In Iran, this situation is very contemplative because the most important principles of labor and social security are ignored. The widespread outbreak of employers' escape from insuring workers and adopting techniques to lessen the employer's share and taking into account the lowest share of insurance on the list provided to insurers and the weakness and lack of backing of workers and employees, due to the lack of independent union and unions, and Strong in defending the interests of the working class and in aligning the government with the employers, has made the work of the individual a terrible and dreadful one. On the other hand, the rigorous obligations of the funds towards the insured and the failure to respond to specific supervisory authorities have turned them into closed and special institutions. Unfortunately, Iran has one of the worst statistics and welfare policies in the welfare state, and the indicators of living in the country are highly inclined to fall and escape international standards. Social security categories, which are one of the most basic pillars for the continuation of social life, are not well-suited in Iran.

The government's administration in all matters and the ruling of the special classes of sovereignty and financial oligarchy have created the current status. The functions of the government serve the interests of specific and highly factional groups, under the influence of sluggish and overwhelming slogans. The government is used by means of tools and, depending on the social conditions, comes in cross-sectional and transient issues. Misguided management and lack of oversight by competent authorities, retirement funds, and subsidiary companies have pushed for exclusion from accountability and transparency. Inappropriate and inappropriate fund performance is undoubtedly a lack of program and a vision for employment policies; when officials can not accurately chart the job market for the next few years, this will be done at the expense of retirement funds; In other words, when the decision to enter is not clear, it is not possible to properly output the output of the boxes, so that the boxes do not have adequate input and output.

Particularly in employment policy, in countries where work is available for work in private or free sectors, workers are trying, as soon as possible to use the law, even occasionally with fewer than 30 or 40 years of work (early retirement) are retired and retired at retirement, while in countries where employment is low, workers tend to increase their length of service Until they receive a reduction after retirement (Talib, 1368, 111). 


\subsection{Ineffective Rules}

The rules for retirement funds over the past two decades, more than non-disciplinary, are more hurried and unsupervised than they are by way of planning and rationality. The laws, which impose a double burden on funds and early retirement, are evidence of this. These laws have been introduced and enforced by the institutions of the government and the parliament or other governing bodies at various historical periods to defend some of the few, as well as the unjust, unfair and unprofitable transfers of harmful enterprises caused by the government's rejection have caused the situation Bad to go Many of the companies that have been entrusted have been completely deprived and bankrupt to the extent that they are not able to pay their workers' salaries and have been put into retirement funds in the form of rejection of dies, and in this context not only did they not contribute to the fund, but also doubled the burden. They are created. In addition, there is no systematic and systematic system in place to categorize hard and harmful businesses, which has led some of the working groups to fail to take advantage of the benefits of social security and retirement.

In addition to this, it should be said that the minimal coverage of the community in terms of retirement benefits suggests another reality; the minister of co-operation, work and social welfare in 1396 said: "There are seven million Iranian retired people who need to retire by distributing their retirement insurance policies Provide Future, Sufficiency and comprehensiveness are the main attributes of the retirement system, and adequacy means providing a decent living for individuals who work in a society that offers decent rates of service and does not have to retire. Most importantly, it is inclusive, and in fact social security coverage should extend its umbrella to all individuals; while 6 million of our employees are still not covered by any insurance, and the most important issue is efficiency The pension system.

The need for suggestions for changing regulations and rules in the field of social policy should ultimately be the precision and observance of all aspects, and in this regard, testing and using expert opinions is absolutely necessary. Approval of the rules of the five-year plan for the development and inclusion of materials that it is impossible to implement and impossible to implement, and without regard to the existing facilities and the current situation, is definitely condemned to failure. Therefore, good governance is another matter that has been implicated in all the recommendations of the International Labor Organization, which has been found in the organization's 102rd affair. Good governance in the insurance system means tripartiteness. Ie the representative of the workers, the representative of the businessmen and the government representative in the fate of the fund. Indeed, under the umbrella of the Social Security Organization Charter, there should be a good governance in the funds, and changes in line with the level of development in each country, and managing the funds with the active participation of all partners and stakeholders Social.

\section{Privatization of Pension Funds}

Privatization is a process that began in the 1980s to reduce the government and reduce its responsibilities to the non-state sector, and its main objective was to reduce the financial burden of non-sovereign government actions and compensate for the severe budget deficits have been. The starting point for this privatization is linked in the United States and Western European countries, whose implementation has been somewhat successful, but privatization in social security, which is also an important part of retirement (due to the costs involved in this area), with resistance And serious opposition. Pension privatization, which is a process in Eastern and Central Europe (Hungary, 1998 Poland, 1999 - Latvia, 2001 - Bulgaria, Croatia and Estonia, 2002 - Lithuania, 2004 - Slovakia, 2005 - Macedonia, 2006 - Romania, 2008), With the support of the World Bank, began reforms. In Eastern and Central Europe, only Slovenia and the Czech Republic have public retirement schemes, but the Czech Republic seeks to introduce the private sector into the pension system. In the financial crisis of 2008, this reformed private pension system was badly damaged and failed to handle well-assigned missions, and re-started the return of structural reforms (re-reforms) and tendency towards public retirement schemes. The failed plan that has been implemented by the World Bank in Eastern Europe and Latin America has resulted in no major failures. A plan to privatize retirement and replace individual funds instead of public funds or so-called insurers: from DB to DC from certain benefits to a given share. The most important thing is the difference between these two risk acceptance funds. In the former, the risk is taken by the worker and the employer and the government, but in the latter, all risks are borne by the worker, and each worker has an individual account where the premium paid by him on these accounts is saved and invested and the balance or the accumulated capital in time His retirement becomes his retirement pension. Privatization requires a clean, transparent economy. In the corrupt economic context of Iran, where inequality and lack of transparency are 
the first and last words, privatization in all fields is doomed to failure; the lack of vision or targeting of inaccessible programs can not be a conduit for Implement privatization.

In 2018, the plan for the efficiency and improvement of pension funds, as well as its title, has been placed on the agenda of the Islamic Consultative Assembly in order to achieve these goals. Multilateral solutions, including debt recovery, increased oversight (oversight board, ministry of welfare, The stock market organization, the market mechanism), and the reduction of fund management costs (through restructuring and merging them), but to what extent the methods and solutions presented in this plan will lead to the productivity and efficiency of retirement funds, It is unclear because of damage And exit factors from the current state of affairs in retirement funds have been neglected. In the parliamentary plan titled "Efficiency and Promotion of Retirement Funds," the Boxing Crisis cites two other environmental and water crises, saying that in the next few years, 50 percent of the current government spending will be spent on the deficit of the retirement funds, and with this argument, claimed in countries Advanced to solve this issue from DB systems to DC systems. The text does not mention individual accounts or DCs, but rather focus on structural change and the strengthening of the fund's supervisor. The plan is intended to form the members of the Supervisory Board: First Vice President, Minister of Commerce, Minister of Economic Affairs, The Minister of Health, the head of the program organization and the head of the Employment Administration, one of the directors of the Funds, three representatives of the parliament and a supervisor of the Pension Fund, which is formed on the proposal of the Ministry of Co-operation, Labor and Social Welfare. It is worth mentioning that no representative of the workers and employers has been proposed on this board, and unfortunately, the failed policy of separation of funds in the final clause of the plan is still unclear, the retirees of the organizations of the organization and the Ministry of Intelligence do not include this plan. Regarding the ineffectiveness of DC systems in Iran, which the government seeks to use for pension funds, it must be acknowledged that current workers and employees are not able to pay their monthly wages due to lack of sufficient financial resources. Assign to participate in individual account management programs with private management. The high current cost of working life and the lack of sufficient coherence in the form of strong unions and strong syndicates that advocate for business interests are unsuccessful reasons for such plans. In addition, the vulnerability and uncertainty of the economic and financial systems and the absolute government of the government should be mentioned as the next obstacles in the privatization and allocation of funds.

According to Article 19 (1) of the Law on the Securities Market of the Islamic Republic of 1384 and Section A of Article 28 of the Law of the 5th Development Plan, the possibility of the activity of private pension funds in the stock market can, because of the mechanisms underlying it, force transparency of funds But this viewpoint is also condemned to failure, since the retirement system in Iran is not at all able to compete with other firms, and usually the investment of funds should be ultimately confident and the certainty of returning capital for the monthly benefits of the benefits; hence Possibility to enter the boxes Retirement to the activities of the stock exchange is not conceivable. Consideration should be given to any change in the retirement funds, given the social, economic, political and cultural context; although poverty eradication and the promotion of social justice are the mission of social security systems, the need for each country should be flexible. Integrity in the implementation and equality of all people (male, female, and unemployed) is a transformation in the agility and efficiency of the funds (Karbassian, 2005, 76).

\section{Ten Essential Principles in the Management of Pension Funds}

Retirement systems are a set of goals and principles that reduce poverty, modify income inequalities by improving redistributive mechanisms, and ultimately protecting citizens from social and economic risks, especially in old age and retirement. . These goals vary according to the social and economic conditions in different countries, which is the difference in the delivery of services and the quality of it, which forms the basis of retirement systems.

The ten basic principles governing retirement pension funds can be used as a starting point and a model for promoting and increasing efficiency: 1 . Social dialogue 2. Coverage 3. Equality 4. Social solidarity 5. Gender equality 6 . The adequacy of the benefits 7 . The efficiency and rationality of the administrative costs 8 . Social partnership in management 9. The government's view and supervision 10. The financial standing.

\section{Remedies for Retirement Funds}

Pension funds all over the world are constantly changing due to the dynamism and responsiveness of people's legal and legal needs. But what is noteworthy is that retirement systems are moving in the context of the situation and in 
the legal framework together with the prospect, and all planning is fully calculated, in such a way that the least harm is to the rights of individuals. To be In the countries of Latin America and Eastern Europe, the serious and inevitable changes that were mandated and implemented by the World Bank were different and different, although the reform policies of the pension system were hardly in Latin America, but in Europe Eastern, somewhat successful. What the Iranian legal system should do about the retirement system is the use of experiences that have already been tested and the effects of which are visible; but it should not be forgotten that any correction should be fully adapted to local and native conditions, and that hasty implementation Corrective policies will lead to the fate of Latin American countries. Among the solutions that have been made during the review of several countries to solve the problems of retirement funds, it can be cited that the Islamic Republic of Iran, including the legislative and executive branches, must be implemented and implemented with the utmost precision.

\subsection{Integration (aggregation) of Pension Funds}

Integration means to squeeze and divide two things; in Article 113 of the Services Management Act, the government is obligated to end the Law on the Fourth Economic, Social and Cultural Development Plan of the Islamic Republic of Iran regarding the aggregation of all pension funds, including country and supply In the social security organization, the social measures required legal action. This organization is a subset of the Ministry of Welfare and Social Security and the Minister is accountable to the relevant law enforcement agencies. Although this legal regulation has come to fate of non-implementation. But it should be kept in mind that the pooling of funds in each other should be related to the variables and factors in order to achieve the required efficiency and objectives. For example: Type of public pension fund and private.

Integration is a two-way process, and its effects can be both positive and negative and, depending on the circumstances and prospects of the two different destinies, aggregation of funds can, if it can, be fruitful that the situation and financial statements and costs, The number of pensioners and resources, and the input and output of each fund they want to merge are clear and merely the integration can not resolve the problems themselves, even the merger in which the problems of the fund are transferred to the other fund is completely Rejected and failed (for example, the opposition to the Parliament in 1396 by integrating the staffing fund of the steel fund with the fund Retirement of another).

\subsection{Create Multi-column System}

In line with the implementation of the ten principles, as mentioned above, in the legal assignments of Article 29 of the Constitution and Article 9 of the Law on the Structure of the Comprehensive Welfare System, which is based on the principle of equality and comprehensiveness (coverage comprehensiveness) and the principle of adequacy Minimality of support) (Naimi and Pardo, 1395, 14 and 13). It should be noted that the solution can be used to create a multilayer system (pillar or column) that is implemented in most countries and can be used to improve the efficiency of funds and improve the conditions for retirees (Sheikh Heidari 2010, 253, and 254) Elderly risk can often be covered through a three-tier insurance system; these layers also have an impact: the first layer - statutory (compulsory or optional) insurance; the second layer - participation in the retirement plans approved in A group insurance (compulsory or optional); a third layer - individual pension arrangements in the private sector (Peters 2009, 116).

The government also seems to have introduced the three-tier system by identifying weaknesses in existing state funds and disadvantages of the social insurance system following the implementation of the multi-layered system, which is included in Article 27 of the Fifth Development Plan. : - Social benefits include support services and the empowerment of basic social insurance, including basic pensions and basic health insurance for supplementary pensions and treatment.

\subsection{Create Transparency}

There is no need for transparency in most pension funds; many funds hide their budgets approved by the Trustee or the High Council and hide their costs and revenues and obligations confidentially, and this is hidden. Failure to report gains and losses can not result in privatization in this area; therefore, transparency and access to information are a very serious condition for entry into the financial market (stock exchange and privatization). In surveys of several funds, many reports have been submitted for a period of three years. 


\section{Conclusion}

Elderly is a time of sophistication and a time of unnecessary feeling and an opportunity to move towards perfection and self-control. Hence, aging can be considered as an effective and costly stage in life. Reviewing retirement funds has a particular complexity, because it has a very strong connection with the social insurance system. Hence, retirement has become a social reality and can not be overlooked and denied in contemporary modern societies. In addition to providing basic retirement needs, this institution can reduce inequality in terms of income and poverty, managing disease risks, managing political risks, increasing employment and contributing to economic development.

Establishing a healthy, competitive and competitive environment, creating a suitable investment environment, changing the rules and regulations of retirement (premiums, retirement age and retirement age, etc.) that are proportional to the principles of pension insurance, optimal management of pension funds, payment of all debts The government can find ways to get out of critical situations. An important point in the changes to the retirement funds is to focus on protecting the interests of the fund's members and providing them with the dignity and respect of their lives, because the philosophy of the fundamentals of fundamentals is the same.

Although systematic reforms (layering and leveling of coatings and financial stabilization based on the type of financing of plans, etc.), parametric (the proportion between life expectancy with age and retirement history, etc.) and reengineering (Regulating and regulating regulations, desirable governance, etc.) and the formation of a multi-layered social security system for retirement funds is necessary; however, minimum conditions for new insured persons and new insurance cover should be imposed. Basically, retirement systems should be designed taking into account the specific circumstances of each country, including the level of development, demographic trends, macroeconomic policies, infrastructure, institutional capacities, and the strength and power of financial markets. In this context, macroeconomic macroeconomic imbalances, high inflation rates and excessive debt burdens lead to uncertainty and instability of pension funds. In this important area of the problems of the country's retirement system, it was necessary to look at the structural problems of the country's macroeconomics; in the course of the upcoming period, the government and the parliament had to come to the aid of the funds and, with a series of measures, prevent the increase in the problems of the funds, and, Maintaining the appropriate level of salary will trigger corrective measures by changing the status of retirement funds, and this will not be possible except in the context of welfare policy, expanding support umbrella and having a dignified and consistent life. With standard standards for the life of a person, because social security and b Asylum is a fundamental right recognized by law. In this way, all facilities, including the legislature and the executive branch, must work to improve the conditions of the pension funds, to satisfy the people of their lives, and to provide them with a decent future for their employees., Be created. Advancing partnerships and partnerships at all levels is possible with the participation of insured persons and other stakeholders, and all groups must feel responsible in the community, since the issue of retirement funds is an international issue and does not have a specific age group. And it's an inclusive thing, which includes all people in the community. Also, the optimal use of the funds of the pension funds should be prioritized, because in fact these resources are made up of the premiums of the employed people and are generally described and should be supported by such property too. In order to close the way of any abuse, the amount of the retirement pension should be significantly reduced, and the principle should always be compulsory retirement.

\section{References}

Akbari, Mohammad Ali. (2016). Social welfare in contemporary Iran(1st ed.). Tehran: Social Security Research Institute.

Araqi, Ezatollah \& Colleagues. (2009). Attending to social security rights (critique of Iran's social security law based on comparative study)(1st ed.). Tehran: Social Security Research Institute.

Badini, Hassan. (2008). Social Security Funds and their Subscribers in the Law on the Administration of National Services. Quarterly Journal of Social Security Laws, 1.

Haidari Sheikh Tabaghi, Parvin. (2010). Fundamentals of Social Security Layer. Journal of Political and Economic Information, 273-274.

Karbassian, Mehdi. (2007). Social Security and Retirement in Iran. Tehran, Public Joint Stock Company.

Mier, Seyed Javad. (2017). Agricultural Jihad's Pension Fund; Challenges and Solutions. Tehran: Institute of Agricultural Planning and Economics Research, Ministry of Agriculture.

Mojtahedi, Mohammad Reza. (2017). Social security rights(1st ed.). Tabriz: Aydin Publishing. 
- (2013). The evolution of retirement systems in the world (Proceedings 2). Tehran: Retirement Fund of the Pension Fund.

Naimi, Omran et al. (2015). Social security law in the current legal order(1st ed.). Tehran: Forest.

Neimi, Imran \& Partoire, Hamid Reza. (2017). Social security rights; with an emphasis on insurance(3rd ed.). Tehran: side.

- (2017), Statistics Fund of the Pension Fund, Tehran, Center for Planning and Development Office of the Pension Fund.

Pitters, Danny. (2014). Social Security, Introduction to Basic Principles. Translated by Faraz Firoozmandi and Samira Ahmadi. Tehran: Publishing House of Knowledge.

Plug, Niels \& Quist, Ian. (2001). Social Security in Europe: Development or Suspension? Hormoz translation Homayoun Pour. Tehran: Social Security Research Institute.

Rohani Zadeh, Mostafa (2007). The Challenges of the Retirement System in JHA Social Security Quarterly. No. 29.

Sturgeon, Cyrus. (2012). Social security rights(7th ed.). Tehran: Amount.

Taleb, Mehdi. (1990). Social Security(2nd ed.). Mashhad: Razavi Cultural Foundation.

Tompson, Lawrence. (2001). Old Age and Wisdom: The Economic Dimensions of Retirement in the Public Sector. Translated by Zohreh Casaei. Tehran: Social Security Research Institute. 